\title{
Genre Perbualan Aneh dalam Hikayat Nakhoda Muda: Analisis Semantik Inkuisitif
}

\section{A Strange Conversational Genre in Hikayat Nakhoda Muda: Inquisitive Semantics Analysis}

\author{
Nur Ezatull Fadtehah Hedel* \& Mary Fatimah Subet \\ Fakulti Bahasa dan Komunikasi, Universiti Malaysia Sarawak, 94300 Kota Samarahan, Sarawak, Malaysia
}

Submitted: 12/3/2021. Revised edition: 2/5/2021 Accepted: 24/05/2021. Published online: 28/6/2021

\begin{abstract}
Oral and written traditions already existed a long time ago which are highlighted through various high value work. These works are processed as a medium to convey a words of advice, reprimand, satire and philosophy as a guide for the readers. The purpose of this study is to study the inquisitive semantics in strange conversational genre folklore. The objectives of this study are to identify utterances that display behaviors that were opposite to the norms of life and analyse the influence of culture and intelligence in folklore. This study is a qualitative study and an exploratory design by using a corpus data which is the Buku Antologi Enam Hikayat by choosing Hikayat Nakhoda Muda. The data were collected based on primary and secondary data and all the data were analysed based on three stages which is script semantics, resonans semantics and inquisitive semantics. Relevance Theory was used in this study. This study also includes the philosophy and intelligence of the previous society and the knowledge from other fields in order to get the concrete answer for every lexical that are used in the folklore. The results found that each lexical used in folklore has its own meaning and need to analyse by using inquisitive semantics analysis.
\end{abstract}

Keywords: Genre, Folklore, Strange Conversational, Inquisitive Semantics Analysis

\section{ABSTRAK}

Tradisi lisan dan tulisan telah wujud suatu ketika dahulu yang diketengahkan melalui pelbagai karya-karya yang tinggi nilainya. Karya-karya tersebut diolah kerana menjadi medium untuk menyampaikan kata-kata nasihat, teguran, sindiran dan falsafah untuk dijadikan pedoman dan sempadan hidup para pembaca. Tujuan kajian ini dijalankan bagi mengkaji semantik inkuisitif dalam genre perbualan aneh cerita rakyat. Objektif kajian ini adalah mengenal pasti ujaran yang memaparkan tingkah laku aneh yang menyalahi norma-norma kehidupan dan menganalisis pengaruh budaya dan akal budi dalam cerita rakyat. Reka bentuk kajian yang dijalankan adalah kajian kualitatif yang menggunakan reka bentuk eksploratori dan menggunakan data korpus iaitu Buku Antologi Enam Hikayat dengan memilih Hikayat Nakhoda Muda untuk dikaji. Kaedah pengumpulan data berdasarkan data primer dan data sekunder manakala data dianalisis berdasarkan tiga peringkat iaitu peringkat semantik skrip, semantik resonans dan semantik inkuisitif. Teori yang mendasari pencarian makna ialah Teori Relevans. Kajian ini juga memasukkan falsafah serta akal budi masyarakat terdahulu, ilmu dari bidang lain dalam mencungkil persoalan penggunaan leksikal-leksikal dalam cerita rakyat tersebut. Hasil kajian mendapati bahawa setiap leksikal yang digunakan dalam cerita rakyat mempunyai makna yang tersendiri dan perlu dirungkai berdasarkan analisis semantik inkuisitif.

Kata kunci: Genre, Sastera Rakyat, Perbualan Aneh, Analisis Semantik Inkuisitif

*Correspondence to: Nur Ezatull Fadtehah Hedel (email: nurezatullfadtehah@gmail.com) 